\title{
工事振動への経験的予測手法の適用性に関する検討 \\ INVESTIGATION ON THE APPLICABILITY OF THE EMPIRICAL PREDICTION METHOD TO CONSTRUCTION VIBRATIONS
}

\author{
津野靖士*1, 野寄真徳*2, 横山秀史*3 \\ Seiji TSUNO, Masanori NOYORI and Hidefumi YOKOYAMA
}

\begin{abstract}
To simply and accurately evaluate construction vibrations, we investigated on the applicability of the empirical prediction method to construction vibrations, using velocity of subsurface layer. We performed measurements for construction vibrations and subsurface structural surveys at a site. Applying the wave propagation equation to construction vibrations, we found that Rayleigh waves affected by subsurface layer were significantly dominated in construction vibrations. Finally, we well reproduced construction vibrations against distances from construction sources by the empirical prediction method based on the theory of wave propagation, focusing on the dominant frequency with phase velocity of surface waves in a subsurface layer.
\end{abstract}

Keywords : Empirical prediction, Construction vibration, Subsurface layer, Rayleigh waves, Surface wave exploration, Array microtremor observation 経験的予測, 工事振動, 表層地盤, レイリー波, 表面波探査, アレー微動観測

\section{1.はじめに}

環境振動の予測分野では，振動源から放射された媒質を伝播する 波の対象地点での振動值を予測するために, 波動伝播理論や伝達関 数を利用した理論的手法や測定データを利用した経験的手法, ある いはそれらを併用した手法が用いられている 1)。一方で，環境振動 の影響評価では, 人の生理的な反応や心理的な反応に基づいて補正 された周波数特性を考慮して, 環境振動が人に影響に与える評価例え ば, 2)を行っている。人の振動に対する感覚はその周波数や方向によ って異なり, 数 $\mathrm{Hz}$ 以下の振動では水平動に感度が高く, 数 $\mathrm{Hz}$ 以 上の振動では鉛直動に感度が高いこと2)が知られている。JIS C $1510^{3)}$ の JIS 規格においても, 水平動と鉛直動で異なった周波数の 補正特性が与えられており, 数 $\mathrm{Hz}$ 以上の高周波数帯に対して鉛直 動の補正係数は水平動のそれよりも相対レスポンスが $10 \mathrm{~dB}$ 程度高 く設定されている。環境振動の大半が数 $\mathrm{Hz}$ 以上の振動が大きい周 波数特性を有しているため, 環境振動を予測する上では, その鉛直 動の加速度值に対する正確な予測がより重要な課題である。

環境振動の予測では, 原理的に半無限媒質を伝播する波動伝播理 論 1), 4)を利用している事例が多い例えば,5)。その中でも, 現地調查の 実測データに基づいた振動予測手法として, ある地点の振幅を参照 した Bornitzによる経験的予測式 6)やそれを簡略化した実用式が一 般的に広く利用されている 1),7)。しかし，それら理論式や実用式の
重要なパラメーターである媒質の速度について, 現地調查などの測 定データから取得した事例は少なく，それら実用式の適用範囲が明 確に示されていないのが現状である。一方で，近年，表層地盤調査 として, 加速度計などのセンサーをアレー状に多数点配置すること で，表層地盤の $\mathrm{S}$ 波速度構造を評価することができる表面波探査 ${ }^{8)}$, 9)やアレー微動観測 10), 11)が実務で広く適用されている。

本研究では, 実測データに基づき, 環境振動の一種である工事振 動を簡易にかつ正確に評価することを目的に，直線状に配置した多 数のセンサーにより地表面加振から励起された工事振動を測定し, 工事振動の波動伝播特性について検討した。調査地の工事振動が伝 播する地盤の速度を取得するために, 表面波探查 ${ }^{12)}$ とアレー微動観 測 13)を実施した。また，表層地盤構造調査の結果と測定した工事振 動を波動伝播理論に適用することで, 地表面加振から励起された工 事振動の波動成分を識別し, 表面波の理論から工事振動に与える地 盤深さの影響を検討した。最後に, 工事振動の卓越する周波数を評 価することで，波動伝播理論に基づいた経験的手法の工事振動への 適用性を実証的に検討した。

\section{2. 工事振動の測定調査}

現地調査地として, 多様な建設重機の使用が予定されていた工事 現場(平塚市内)を選定した。その工事現場において，2015 年 12 月

\footnotetext{
*1 (公財) 鉄道総合技術研究所 副主任研究員・博士 (工学

*2 (公財) 鉄道総合技術研究所 研究員・修士 (工学)

*3 (公財) 鉄道総合技術研究所 主任研究員・博士 (工学 $)$
}

Assist. Senior Researcher, Railway Technical Research Institute, Dr.Eng.

Researcher, Railway Technical Research Institute, M.Eng.

Chief Researcher, Railway Technical Research Institute, Dr.Eng. 
22 日と 2016 年 1 月 14 日の深夜に工事の振動測定を行った。測定 には, リオン(株)製の振動レベル計(VM-52・VM-53)8〜10 台とティ アック(株)製のデータレコーダ LX-110を使用し, 合計 $24 \sim 30$ チャ ンネルで 3 成分の工事振動を収録した。センサーは直線上に $5 \mathrm{~m}$ 間 隔で 8〜10 台配置した。環境振動では $60 \mathrm{~Hz}$ 以上の高周波数帯も対 象領域であるため, それら周波数帯域の波形がトレースできるよう に, サンプリング周波数を $3 \mathrm{kHz}$ とした。対象とした工事は, 大型 の建設重機(例えば, $20 \mathrm{t}$ 級のパワーショベルやブルドーザー)による 整地作業と土留め作業などであり, パワーショベル(地面吒きと土落 とし)やブルドーザー, サイレントパイラーの異なる 4 種類の振動源 による工事振動を測定した。Fig.1 に, 配置したセンサーと工事振 動源の位置関係を示す。Table1 に, 工事振動の測定概要を示す。パ ワーショベル(地面吒きと土落とし)とサイレントパイラーの測定で は, 振動源から $2 \mathrm{~m}$ の距離に最も近接の測定点(Fig.1 では, 本測定 点を $\mathrm{x}=0, \mathrm{y}=0$ の原点とした)を配置した。ただし，Fig.1(ロ: $-5 \leqq \mathrm{x} \leqq$ $5, y=5)$ に示すようにブルドーザーによる加振はセンサーを配置し た直線アレーに平行な往復動作であり, 近接の 2 つのセンサーに対 しては振動源から $5 \mathrm{~m}$ の距離であった。なお， P-1 と P-2 はパワー ショベルによる地面吒きと土落とし， B はブルドーザー， S はサイ レントパイラーによる振動である。

工事振動源から最も近い $2 \mathrm{~m}$ 地点と $22 \mathrm{~m}$ 離れた地点(ただし, そ れら地点は, ブルドーザの振動源から $5 \mathrm{~m}$ と $15.8 \mathrm{~m}$ が最短距離とな る)に設置したセンサーで収録された各種工事振動の上下動加速度 波形を Fig. 2 に示す。振動源から $2 \mathrm{~m}$ の地点では最大加速度で
$100 \mathrm{~cm} / \mathrm{s}^{2}$ を超える上下振幅を記録し, 振動源から $22 \mathrm{~m}$ 離れた地点 では, 最大加速度で $10 \mathrm{~cm} / \mathrm{s}^{2}$ を超える上下振幅を記録した(Fig.2)。 Fig. 2 に示した工事振動源から最も近い $2 \mathrm{~m}$ 地点と $22 \mathrm{~m}$ 離れた地点 における上下動加速度波形のフーリエ・振幅スペクトルを Fig.3 に 示す。その上下動成分の周波数特性については, 振動源から $2 \mathrm{~m}$ の 地点では周波数 4〜 $40 \mathrm{~Hz}$ で卓越し, 振動源から $22 \mathrm{~m}$ 離れた地点で は周波数 4 $10 \mathrm{~Hz}$ が卓越していることが分かる。このことは, 工事 振動の上下動成分は, 距離減衰とともに振幅が低下し, 高周波成分 ほど減衰の効果が強いことを示唆している。また，パワーショベル やブルドーザー, サイレントパイラーの異なる振動源(Table1 の $\mathrm{P}-1 \cdot \mathrm{P}-2 \cdot \mathrm{B} \cdot \mathrm{S})$ による工事振動については, パワーショベルでは 周波数 $5 \mathrm{~Hz}$ 付近が卓越し, ブルドーザーでは周波数 $12 \mathrm{~Hz}$ 付近が卓 越するなど, 建設重機により励起される周波数帯が異なることが分 かる。

Fig.4 に, 振動源から最も近い $2 \mathrm{~m}$ 地点と $22 \mathrm{~m}$ 離れた地点におけ るパワーショベルの地面吒き $(\mathrm{P}-1)$ にる水平動(Radial 成分と Transverse 成分) と上下動加速度波形のフーリエ・振幅スペクトル を示す。最も近い $2 \mathrm{~m}$ 地点では Transverse 成分が大きく, $22 \mathrm{~m}$ 離 れた地点では上下動成分が大きいなど, 水平動と上下動の波動伝播 特性が異なることが示唆される。しかし, 環境振動では上下動成分 の評価がより重要であるため, 本論文では上下動成分に焦点を絞り, その波動伝播特性を検討する。なお, 直線上に配置したセンサーで 収録された上下動のアレー加速度波形を Fig.5 に示しているが, 異 なる振動源による工事振動は距離とともに減衰しながら伝播してい る様子が分かる。

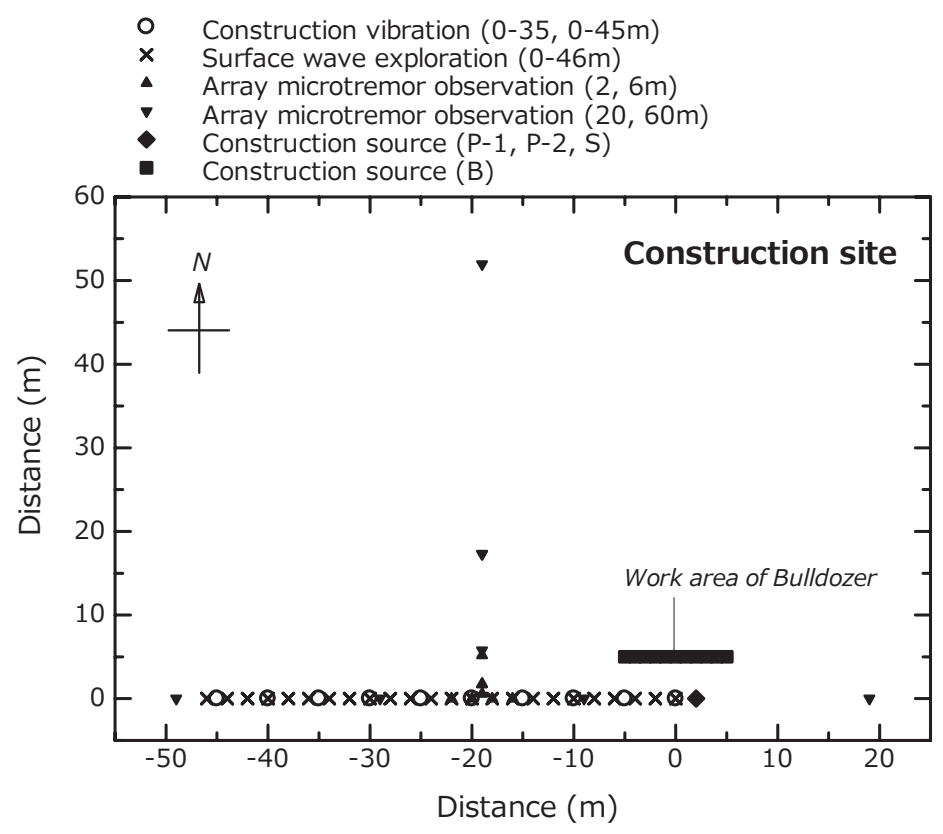

Fig.1 Configuration of measurements and surveys in this study

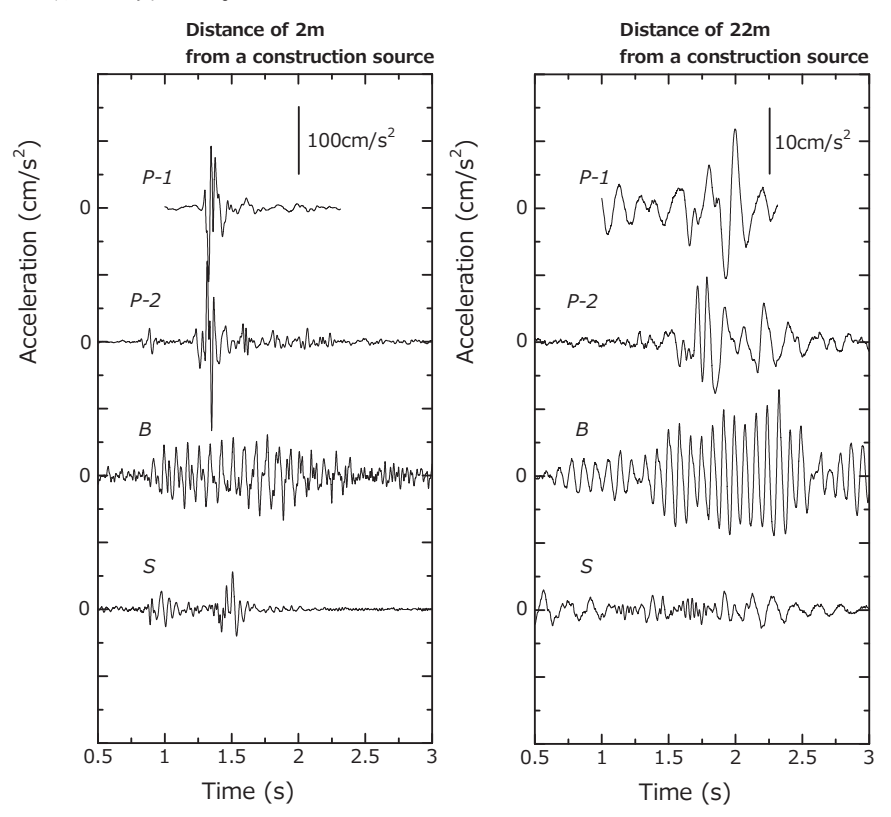

Fig.2 Vertical accelerations

at points of $2 \mathrm{~m}$ (left) and $22 \mathrm{~m}$ (right) from construction sources

Table1 Details of measurements of construction vibrations

\begin{tabular}{c|ccc} 
Constrcution source & Configuration of an array $(\mathrm{m})$ & Sampling frequency & Sensor \\
\hline Power Shovel (g.s.): P-1 & Linear array: $0,5,10,15,20,25,30,35$ & $3 \mathrm{kHz}$ & PV-83 (Accelerometer) \\
Power Shovel (s.d.): P-2 & Linear array: $0,5,10,15,20,25,30,35$ & $3 \mathrm{kHz}$ & PV-83 (Accelerometer) \\
Bulldozer: B & Linear array: $0,5,10,15,20,25,30,35$ & $3 \mathrm{kHz}$ & PV-83 (Accelerometer) \\
Silent Piler: S & Linear array: $0,5,10,15,20,25,30,35,40,45$ & $3 \mathrm{kHz}$ & PV-83 (Accelerometer)
\end{tabular}

* g.s.: ground slap, s.d.: soil drop 

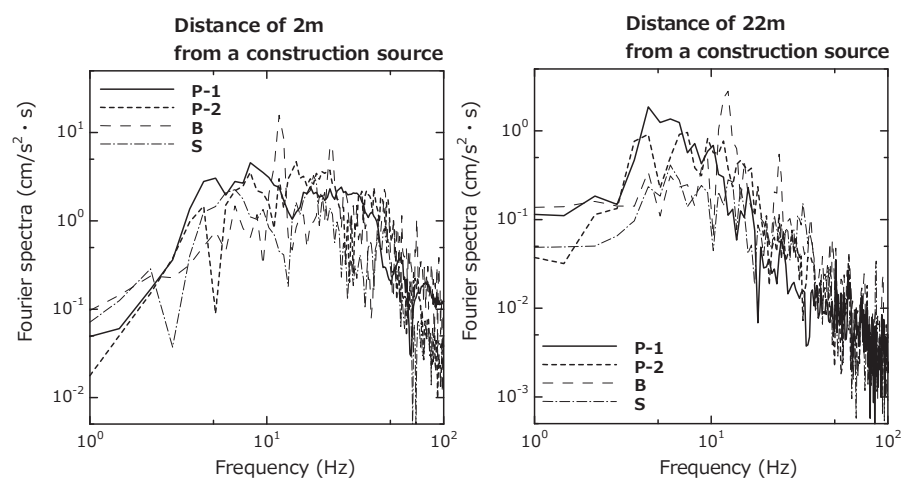

Fig.3 Fourier spectra, using vertical accelerations at points of $2 \mathrm{~m}$ (left) and $22 \mathrm{~m}$ (right) from construction sources
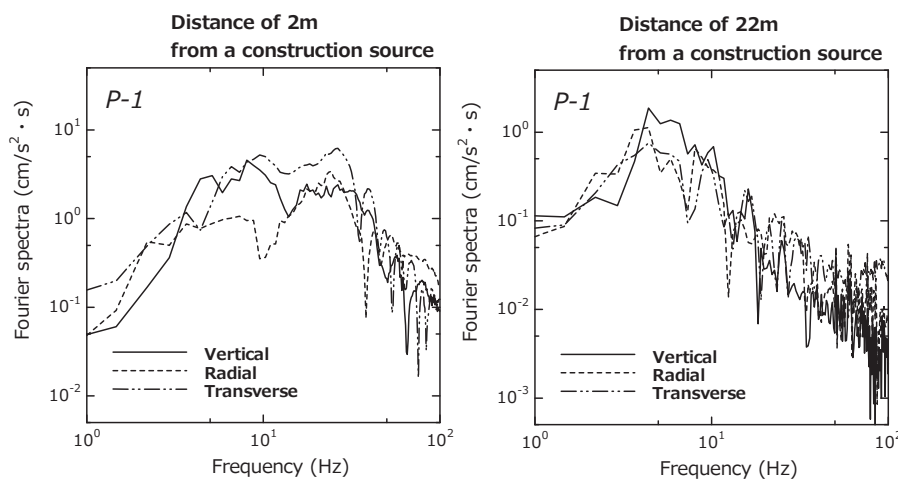

Fig.4 Fourier spectra, using accelerations of vertical, radial and transverse components at points of $2 \mathrm{~m}$ (left) and $22 \mathrm{~m}$ (right) from a construction source of $\mathrm{P}-1$
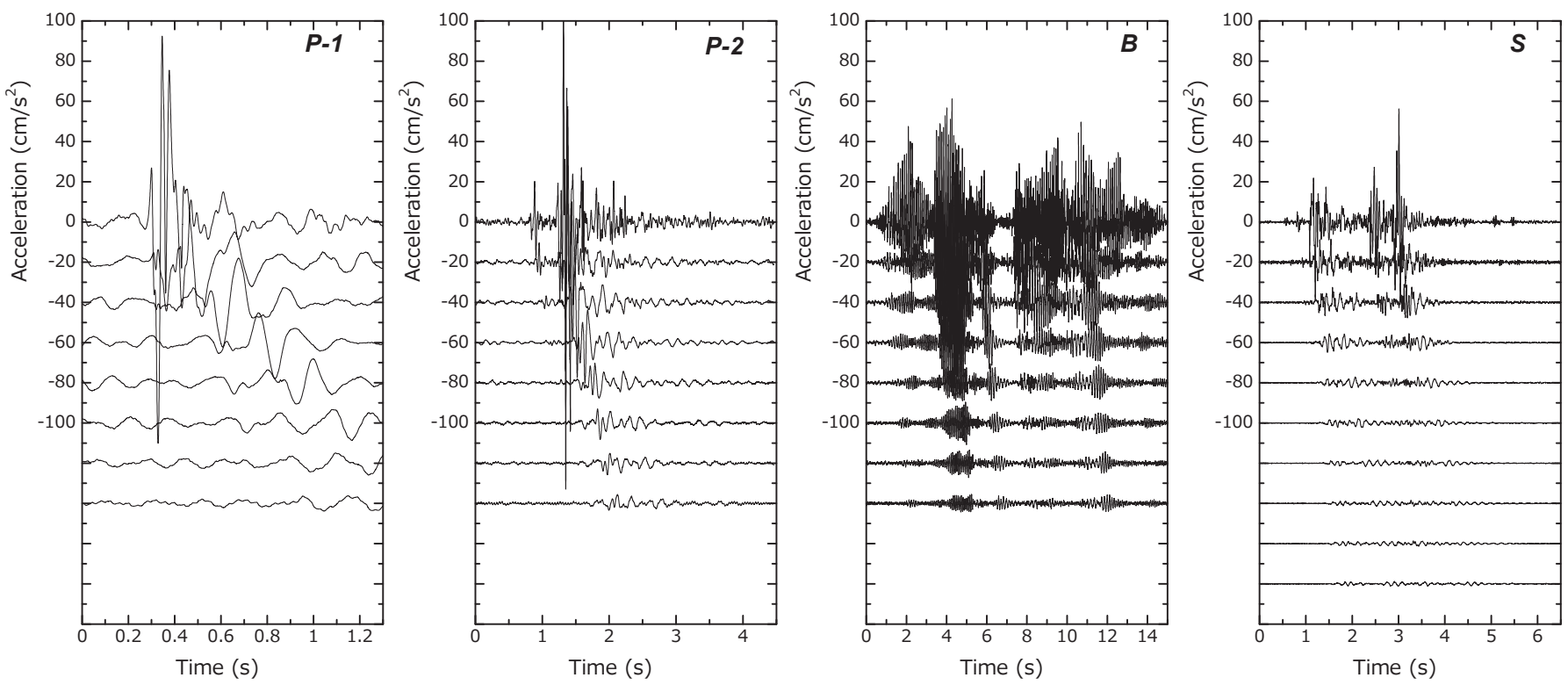

Fig.5 Vertical accelerations for construction vibrations in a linear array at a site in Hiratsuka

(P-1: Ground slap by Power Shovel, P-2: Soil drop by Power Shovel, B: Bulldozer, S: Silent Piler)

Table2 Details of surveys for estimating subsurface velocity and its structure

Survey

Surface wave exploration Array microtremor observation
Configuration of an array $(\mathrm{m})$ Linear array: intarval of $2 \mathrm{~m}$ for an array of $46 \mathrm{~m}$ Double triangles: side length $=(2,6),(20,60)$
Sampling frequency

$1 \mathrm{kHz}$

$100 \mathrm{~Hz}$
Sensor $4.5 \mathrm{~Hz}$ (Velocimeter) Jep-6A3-10 (Accelerometer) 
和しており，レイリー波位相速度が精度良く算出されていることが 分かる。この図が示唆しているように, 測線長が同程度の表面波探 查とアレー微動観測では, 表面波探査から短周期側, アレー微動観 測から長周期側の位相速度が推定される。なお, アレ一微動観測で は, アレー半径が大きくなるほど, 長波長の(あるいは長周期の)表 面波を捉えることができる。

次に, 得られた基本モード・レイリー波位相速度に遺伝的アルゴ リズム(GA)15)を適用し, 表層の S 波速度構造を推定した。Fig.7 に は, Haskell-Matrix から計算した理論解 16)によるレイリー波位相 速度を併せて示す。理論による位相速度は測定から得られた周波数 1.8 $20 \mathrm{~Hz}$ の位相速度と整合性が高く, その周波数帯に影響を及ぼ す表層の $\mathrm{S}$ 波速度構造が精度良く推定されている。Fig.7 に示した 表層の $\mathrm{S}$ 波速度構造から, 本調查地では, Vs $50 \mathrm{~m} / \mathrm{s}$ 程度の最表層 が約 $3.5 \mathrm{~m}, \mathrm{Vs} 100 \mathrm{~m} / \mathrm{s}$ 程度の層が約 $10 \mathrm{~m}$ 堆積していることが分か る。

\section{4. 工事振動の予測手法}

\section{（1）工事振動のスペクトル予測式}

ある点に加振力がかかったのち, 励起された振動が半無限媒質を 伝播する際の振動スペクトルは理論的に式(1)で表現される ${ }^{4)}$

$$
P(f)=S(f) * \frac{1}{r^{n}} \exp \left(-\frac{\pi f r}{V Q}\right)
$$

ここで, $P(f)$ は予測地点の振動スペクトル， $S(f)$ は加振力のスペ クトル,$r$ は加振源からの距離, $f$ は周波数, $V$ と $Q$ は媒質の地盤 速度と内部減衰である。幾何減衰 $\left(1 / r^{n}\right)$ については, 実体波の場合 $n$ は 1 , 表面波の場合 $n$ は 0.5 である。

加振源からの距離が $r_{a}$ の $\mathrm{A}$ 地点に対する加振源からの距離が $r_{b}$ の $\mathrm{B}$ 地点の振幅比 $P_{b}(f) / P_{a}(f)$ は, 式(1)を用いて, 式(2)で表すことが できる。

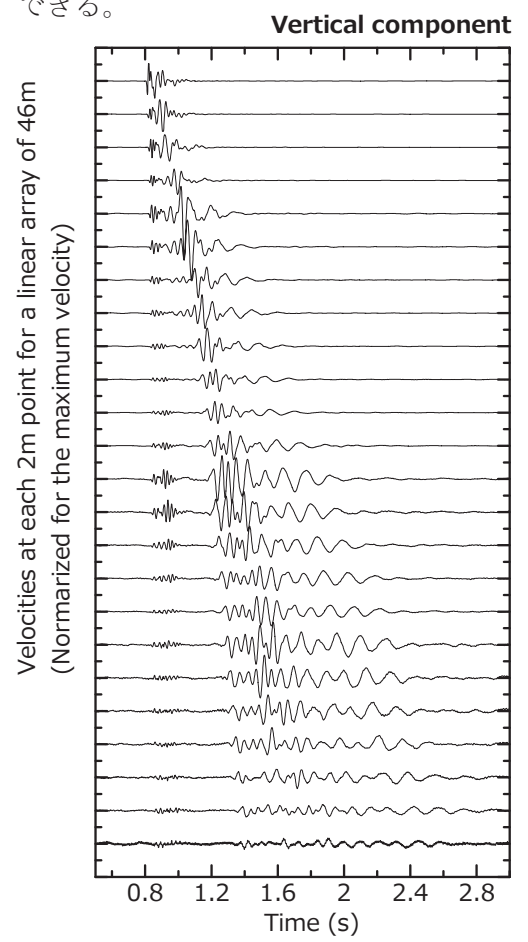

$$
P_{b}(f) / P_{a}(f)=\frac{r_{a}{ }^{n}}{r_{b}{ }^{n}} \exp \left(-\frac{\pi f\left(r_{b}-r_{a}\right)}{V Q}\right)
$$

A地点をリファレンスとし, 加振源からの距離が $r$ である任意地点 に対する振動のスペクトル予測式は, 式(2)を用いて, 式(3)で表すこ とができる。

$$
P(r, f)=\frac{r_{a}^{n}}{r^{n}} \exp \left(-\frac{\pi f\left(r-r_{a}\right)}{V Q}\right) \times P_{a}(f)
$$

ここで，ある卓越する周波数 $f_{1}$ に対して，A地点をリファレンスと した加振源距離 $r$ の任意地点に対する振動スペクトルを予測する場 合は，媒質の地盤速度 $V$ と内部減衰 $Q$ 值である 2 つハパラメーターが 未知数となる。ただし，一般的にはVの方が $Q$ 值より值が大きいた
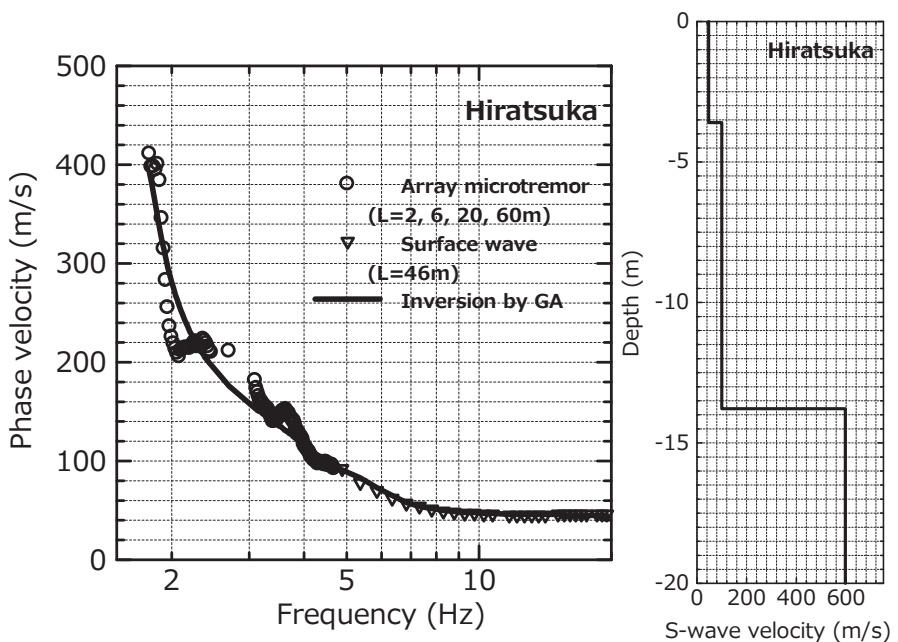

Fig.7 Phase velocity of Rayleigh waves (left) and the estimated S-wave velocity structure (right) at a site in Hiratsuka

Surface wave exploration - Hiratsuka

dB

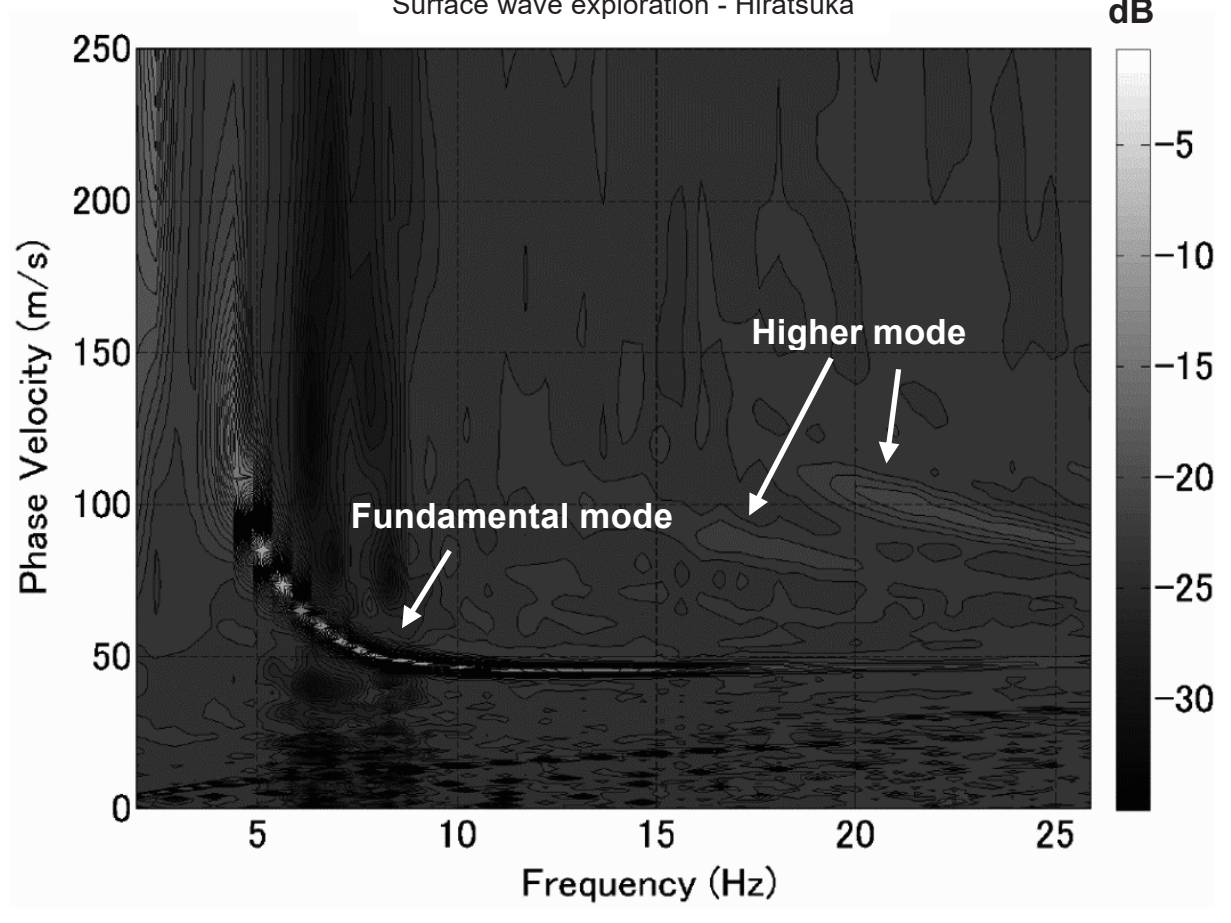

Fig.6 Array velocities by the surface wave exploration (left) and the F-K power spectra (right) at a site in Hiratsuka 


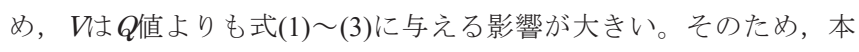
検討では，Vについては実測データを利用し，Q值については経験的 な値を利用している。

\section{（2）波動成分に関する検討}

Fig.2 と Fig.3に示す測定データ(上下動成分)を利用して, 振動源か ら $2 \mathrm{~m}$ 離れた地点 $\mathrm{A}$ に対する振動源から $22 \mathrm{~m}$ 離れた地点 $\mathrm{B}$ の振幅比 $P_{b}(f) / P_{a}(f)$ Fig. 8 に示寸。周波数 $20 \mathrm{~Hz}$ までの振幅比は, 周波数が高 くなるにつれて減衰しているが, 周波数 $20 \mathrm{~Hz}$ 以上の振幅比は摇動し ていることが分かる。これは, 表面波探査結果(Fig.6)から推察する ことができ, 周波数 $20 \mathrm{~Hz}$ まではレイリー波の基本モードが卓越 $(V$ $50 \mathrm{~m} / \mathrm{s}$ 程度 $)$, 周波数 $20 \mathrm{~Hz}$ 以上は高次モードが卓越 $(V 100 \mathrm{~m} / \mathrm{s}$ 程度 $)$ していることが一因である。つまり, 表面波が伝播寸る場合は, 速

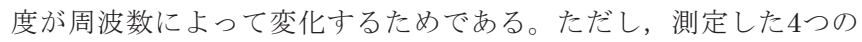
工事振動に対寸る伝播特性に多少の差異が表れている(Fig.8)が，建 設重機の規模や動作による加振点(あるいは加振面)のひろがり, 加 振点の若干のずれなど, 建設重機を加振する環境に依存していると 考えられる。

Fig.8には，予測式(2)において， $n$ を0.5とした場合(表面波)，nを 1とした場合(実体波)の2ケースによる結果を併せて示している。 $V$ は表層地盤構造調查の結果(Fig.6 と Fig.7)を参照して $50 \mathrm{~m} / \mathrm{s} ， Q$ 值は 経験的に 10 とした。この図から明らかなように, $n$ を 1 とした場合(実 体波)の予測式は観測結果を過小評価しているが, $n$ を 0.5 とした場合 (表面波)の予測式は観測結果と調和している。したがって, 地表面 に加振力を与えた工事振動は, 表面波成分が卓越し, 地盤を伝播し ていると結論付けられ, 式(1)〜(3)の地盤速度 Vには表面波の位相速 度を与えるべきであることが分かる。本検討では，上下動成分の工 事振動データを対象としていることから, 式(1)〜(3)の地盤速度 Vと して，対象サイトのレイリー波位相速度を与えれば良い。

\section{（3）表層地盤に関する検討}

次に, $n$ を 0.5 (表面波)に固定し, 予測式(2)において, $V$ を $50 \mathrm{~m} / \mathrm{s}$, $100 \mathrm{~m} / \mathrm{s}$ とした場合の 2 ケースによる結果を Fig.9 に示す。周波数 $20 \mathrm{~Hz}$ まではレイリー波の基本モードが卓越( $V=50 \mathrm{~m} / \mathrm{s}$ 程度)してい るため, $20 \mathrm{~Hz}$ までの周波数に対しては $V=50 \mathrm{~m} / \mathrm{s}$ の予測式の方が $V=100 \mathrm{~m} / \mathrm{s}$ の予測式よりも観測結果と調和している。一方で, 周波 数 $20 \mathrm{~Hz}$ 以上は高次モードが卓越 $(V=100 \mathrm{~m} / \mathrm{s}$ 程度)しているため, $20 \mathrm{~Hz}$ 以上の周波数に対しては $V=100 \mathrm{~m} / \mathrm{s}$ の予測式の方が $V=50 \mathrm{~m} / \mathrm{s}$ の予測式よりも観測結果と調和していることが分かる。ただし， Fig. 3 に示すように, 加振源から最も近い $2 \mathrm{~m}$ 地点と $22 \mathrm{~m}$ 離れた地 点で, 周波数 $10 \mathrm{~Hz}$ 付近が卓越しているため, それらに対応寸る本 調查地のレイリー波位相速度(Fig.6)を考慮して, 地盤速度を一定值 である $V=50 \mathrm{~m} / \mathrm{s}$ として問題はない。

以上, 表面波を仮定し(式(1)〜(3)において $n=0.5)$, サイトのレイ リー波位相速度を振動スペクトルの予測式(2)に与えることにより, 工事振動を適切に予測できることを実証的に示した。

\section{5. 対象地点に対する工事振動の最大加速度の予測}

ここでは, 予測式(3)を用いて, 工事振動源から最も近い $2 \mathrm{~m}$ 地点 (パワーショベルとサイレントパイラーの場合)と $5 \mathrm{~m}$ 地点(ブルドー

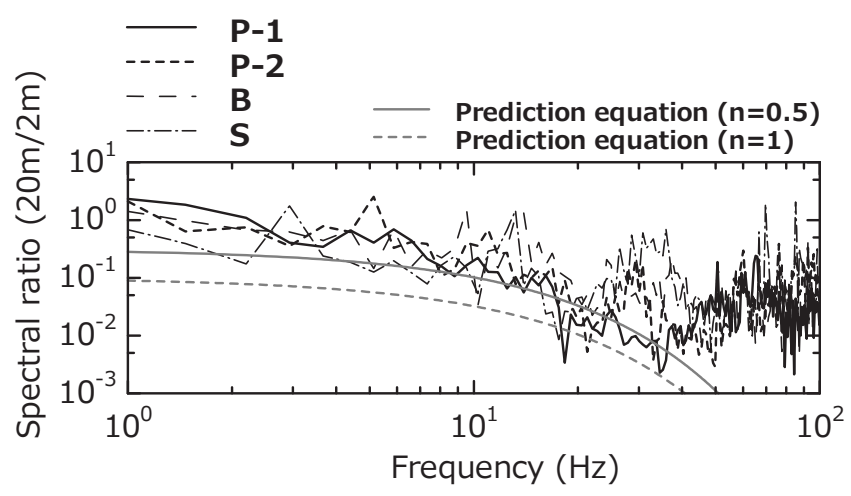

Fig.8 Spectral ratios of construction vibrations at $22 \mathrm{~m}$ from a source to those at $2 \mathrm{~m}$. Also, prediction equation for surface waves $(n=0.5)$ and body waves $(n=1)$ are shown.

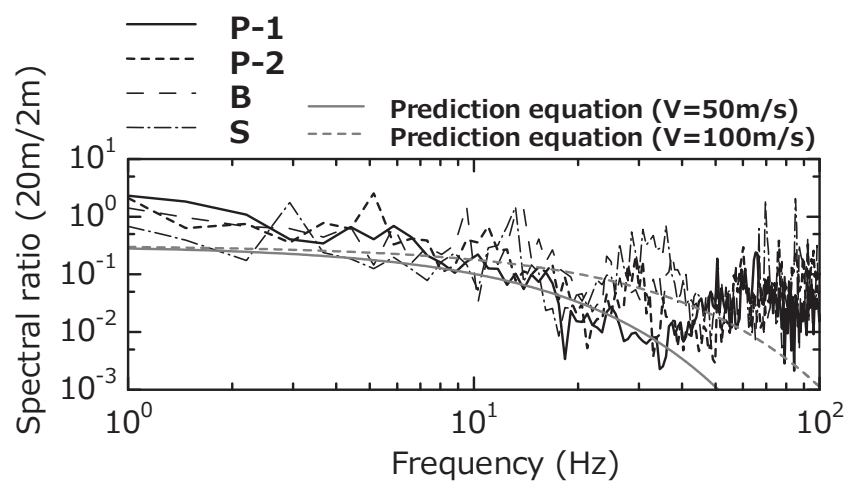

Fig.9 Spectral ratios of construction vibrations at $22 \mathrm{~m}$ from a source to those at $2 \mathrm{~m}$. Also, prediction equation for $\mathrm{V}=50$ $\mathrm{m} / \mathrm{s}$ and $\mathrm{V}=100 \mathrm{~m} / \mathrm{s}$ are shown.

ザーの場合)をリファレンスとした加振源距離 $r$ の任意地点に対す る最大加速度 $(\mathrm{PGA})$ を予測した。その際, 測定データより周波数 4 $\sim 10 \mathrm{~Hz}$ の工事振動が卓越していたこと(Fig.3)から, 周波数 $5 \mathrm{~Hz}$ と 周波数 $10 \mathrm{~Hz}$ に対する各種工事振動を予測した。なお, 調查地の表 層地盤構造調查の結果(Fig.6 と Fig.7)を参考に, 地盤速度(レイリー 波位相速度) $V$ は $50 \mathrm{~m} / \mathrm{s}$, 内部減衰 $Q$ は 10 とした。

工事振動の直線アレー測定データによる最大加速度(PGA) と予測 式(3)を用いた予測結果を Fig.10（図中，P-1 と P-2 はパワーショベ ルによる地面吒きと土落とし， B はブルドーザー， $\mathrm{S}$ はサイレント パイラーによる振動)に示す。図より，4 種類すべての工事振動に対 して, 周波数 $5 \mathrm{~Hz}$ に対寸る予測結果よりも, 周波数 $10 \mathrm{~Hz}$ に対する 予測結果の方が，アレー測定データによる最大加速度(PGA)を正確 に予測していることが分かる。このことは, 予測式(3)において, リ ファレンスとした工事振動源から $2 \mathrm{~m}$ 地点と $5 \mathrm{~m}$ 地点の $P_{a}(f)$ は周波 数 $5 \mathrm{~Hz}$ よりも周波数 $10 \mathrm{~Hz}$ が優勢であること(Fig.3)，また周波数 $5 \mathrm{~Hz}$ の地盤速度(レイリー波位相速度)は $80 \mathrm{~m} / \mathrm{s}$ 程度であるものの周 波数 $10 \mathrm{~Hz}$ の地盤速度は $50 \mathrm{~m} / \mathrm{s}$ 程度であり (Fig.6), 周波数 $10 \mathrm{~Hz}$ の 地盤速度の方が予測式に利用した地盤速度 $V=50 \mathrm{~m} / \mathrm{s}$ と調和するこ とが理由である。

以上, 1 地点の測定データとその卓越周波数を参照し, 調查地の 表層のレイリー波位相速度を利用することにより, 加振源距離 $r$ の 任意地点に対する工事振動の上下動成分に対する最大加速度(PGA) 

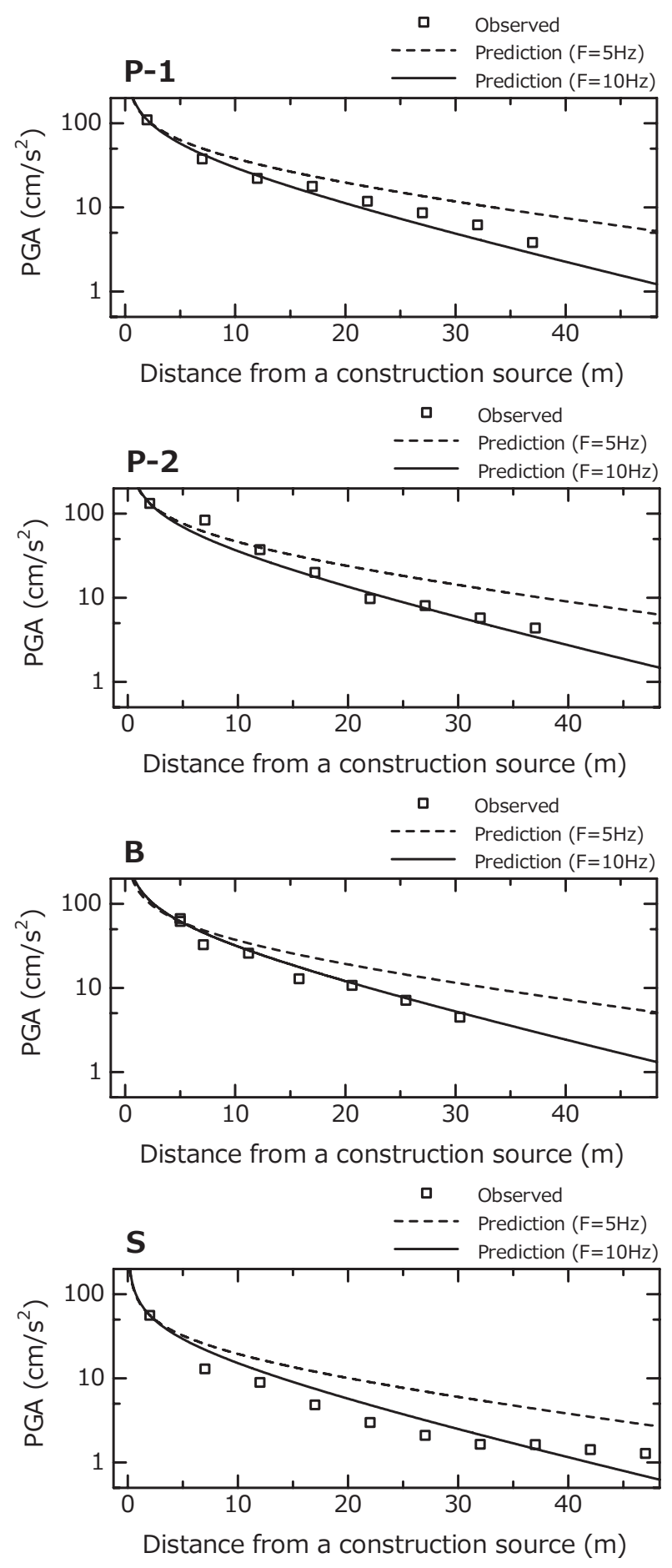

Fig.10 Predictions of PGA against a distance from a construction source at frequencies of 5 and $10 \mathrm{~Hz}$, using the equation (3) with PGA at a point of $2 \mathrm{~m}$ or $5 \mathrm{~m}$ nearby construction sources. The observed PGAs for 4 construction vibrations also are shown. (P-1: Ground slap by Power Shovel, P-2: Soil drop by Power Shovel, B: Bulldozer, S: Silent Piler)

を適切に予測することができることを明らかにした。一方で，工事 振動の水平動成分を予測する際には, 表層のラブ波位相速度も考慮 する必要があり, その場合には水平動の Transvers 成分と Radial 成分の波動伝播に影響を与える表面波(ラブ波とレイリー波)の位相
速度を把握する必要がある。なお，本研究で実施した小規模のアレ 一微動観測や表面波探查を実施することで, 表層の表面波位相速度 を簡易に把握することができる。

\section{6. 工事振動に与える地盤深さの影響}

工事振動の波動成分に関する検討結果(Fig.8)より，工事振動は主 として表面波が卓越していることが示された。表面波は，地盤表面 の伝播方向に対しては, 式(1)～(3)に示すように加振源からの距離 $r$ の平方根(式(1) (3)において $n=0.5)$ に比例した幾何減衰を有してい る。一方で，深度方向については，地表から指数関数的に振幅が小 さくなるといった特性を有している17)。その表面波の鉛直方向に対 する特性を考虑して, 本調查地の表層地盤速度構造がレイリー波で ある工事振動の上下動成分に与える影響を評価した。

現地調查を行った平塚市の工事現場では，表面波探査とアレー微 動観測より表層の $\mathrm{S}$ 波速度構造(Fig.7)が推定されているため，その 推定構造に対する基本モード・レイリー波の地中振幅分布(固有関 数)を計算した。工事振動の測定結果では，振動源から最も近い $2 \mathrm{~m}$ 地点と $22 \mathrm{~m}$ 離れた地点で, 周波数 $4 \sim 10 \mathrm{~Hz}$ が共通して卓越してい たため(Fig.3), それら帯域中における周波数 $5 \mathrm{~Hz}$ と $10 \mathrm{~Hz}$ の地中振 幅分布を Fig.11 に示す。この図から, 周波数 $5 \mathrm{~Hz}$ では深さ $10 \mathrm{~m}$ 程 度の表層構造, 周波数 $10 \mathrm{~Hz}$ では深さ $3 \mathrm{~m}$ 程度の表層構造の影響を 強く受けていることが分かる。このことは, 周波数 $10 \mathrm{~Hz}$ の表面波 の方が，周波数 $5 \mathrm{~Hz}$ の表面波よりも波長 $\lambda(=$ (位相速度/周波数)が短 いことを示している。調查地の表層地盤構造に依存するものの, 周 波数 $10 \mathrm{~Hz}$ 付近が卓越している本工事振動では表層から $3 \mathrm{~m}$ 程度以 浅の構造が振動評価に特に重要である。したがって, コストのあま りかからない規模の小さなアレー微動観測や表面波探查などの浅層 構造調查を実施することにより，サイトに固有する工事振動の伝播 や対象地点での工事振動の大きさを予測することができる。

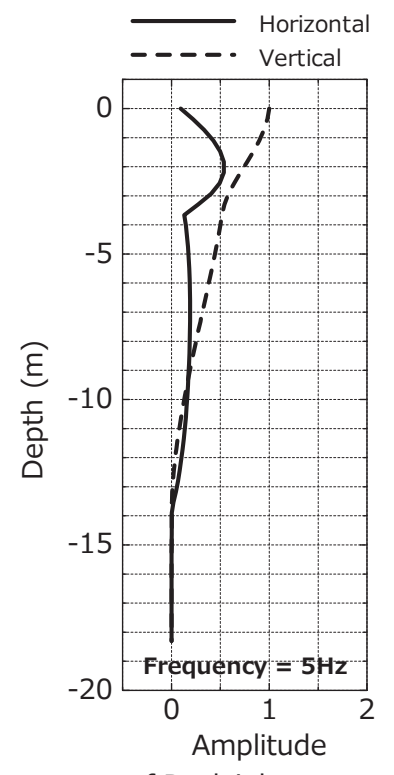

of Rayleigh waves

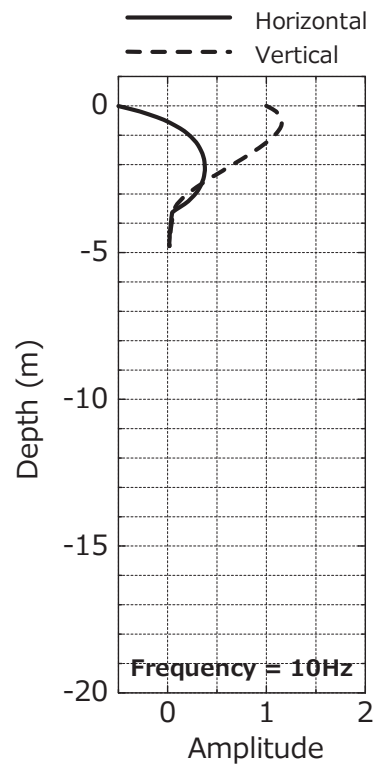

of Rayleigh waves
Fig.11 Distributions of amplitudes of the fundamental mode Rayleigh waves for $5 \mathrm{~Hz}$ and $10 \mathrm{~Hz}$ against a depth at the site (Normalized for an amplitude of vertical motion on the surface) 


\section{7. まとめ}

本研究では, 工事振動を簡易にかつ正確に評価することを目的に, 実測データに基づき, 工事振動への経験的予測手法の適用性につい て検討した。その結果, 対象サイトの表層の地盤速度(レイリー波位 相速度) とリファレンスとした工事振動の卓越周波数を適切に評価 することで, 波動伝播理論に基づいた経験的予測式から, 任意地点 の工事振動を正確に予測することが可能であることを実証的に示し た。

工事振動の測定調查と表層地盤構造調查の実測データを利用した 本検討から得られた知見を, 以下に纏めた。

・平塚市の工事現場において, 異なる 4 種類の振動源による工事振 動を多チャンネルの直線アレーで測定し, 周波数 $4 \sim 10 \mathrm{~Hz}$, 特に $10 \mathrm{~Hz}$ 付近の周波数で工事振動が卓越していることが分かった。

・表面波探查とアレー微動観測による表層地盤構造調查を実施した 結果, 調査地の詳細な地盤情報を取得することができた。本調查地 では，Vs $50 \mathrm{~m} / \mathrm{s}$ 程度の最表層が約 $3.5 \mathrm{~m} ， \mathrm{Vs} 100 \mathrm{~m} / \mathrm{s}$ 程度の層が約 $10 \mathrm{~m}$ 堆積していることが分かった。

-工事振動測定データと理論的な振動スペクトルの予測式から, 地 表面に加振力を与えた建設重機による工事振動は, 表面波成分が卓 越し，地盤を伝播していると結論付けられた。

・また，上記調查による表層地盤のレイリー波位相速度を与えるこ とにより，波動伝播理論に基づいた経験的手法の予測式から，工事 振動を適切に予測できることを実証的に示した。

・1 地点の測定データとその卓越周波数を参照し, 対象サイトの表 層の地盤速度(レイリー波位相速度)を利用することにより, 加振源 距離 $r$ の任意地点に対する工事振動の最大加速度(PGA)を適切に予 測することができることを明らかにした。

・本調査地の表層地盤速度構造から計算された基本モード・レイリ 一波の地中振幅分布により, 周波数 $10 \mathrm{~Hz}$ 付近が卓越している本工 事振動では表層から $3 \mathrm{~m}$ 程度以下の構造が振動評価に特に重要であ ることを明らかにした。したがって，今後は，規模の小さなアレー 微動観測や表面波探查などの浅層構造調查を実施することにより, サイトに固有する工事振動の伝播や対象地点での工事振動の大きさ を予測することができる。

本論文では，環境振動の影響評価でより重要である上下動成分に ついて検討を行ったが，建屋内を伝播する波の水平動は建物の共振 現象より数 $\mathrm{Hz}$ 以下の振動成分において増幅することが考えられる ため，今後は，工事振動を建物に入力することを前提として水平動 成分に対する工事振動の予測についても検討する予定である。

\section{謝辞}

現地調查では，東海旅客鉄道株式会社・岩田裕一氏ならびに多く の方々のご協力を得ました。查読者から頂いた有益なコメントと助 言は，本原稿の改善に大いに役立ちました。記して，感謝いたしま す。

\section{参考文献}

1) Institute of Noise Control Engneering: Regional Environmental Vibration, Gihodo Shuppan, 2001 (in Japanese) 社団法人日本騒音制御工学会 : 地域の環境振動, 技報堂出版, 2001

2) Miwa, T. and Yonekawa, Y.: Evaluation Methods for Sinusoidal Vibrations (Evaluation Methods for Vibration 1), Vol. 27, No. 1, pp.11-20, 1971.1 (in Japanese)

三輪俊輔, 米川善晴 : 正弦振動の評価法（振動の評価法 1), 日本音響学 会誌, 27 巻, 1 号, pp.11-20, 1971.1

3）日本規格協会：振動レベル計，JIS C 1510, 1995

4) Society of Theoretical Earthquake Ground Motion: Earthquake Ground Motion, Kajima Institute Publishing, 1994 (in Japanese) 理論地震動研究会: 地震動 その合成と波形処理, 鹿島出版会, 1994

5) Katayama, T., Tobita, J., Fukuwa, N. and Wakayama, T.: Ground Vibration Caused by Construction of Subway Station Using Diaphragm Wall Method, Journal of Structural Engineering, Vol. 46B, pp.483-496, 2000.3 (in Japanese)

片山貴裕，飛田潤，福和伸夫，若山武彦：連続地中壁工法による地下鉄 駅建設工事に伴う地盤振動の発生と伝播, 構造工学論文集, 第 46B 巻, pp.483-496, 2000.3

6) Bornitz, G.: Uber die Ausbreitung der von Grosskolbenmaschinen erzeugten Bodenschwingungen in die Tiefe, J. Springer, 1931

7) Shioda, M.: Prediction and Reduction for Environmental Vibration, Acoustical Society of Japan, Vol. 60, No. 9, pp.549-554, 2004.9 (in Japanese)

塩田正純 : 環境振動の予測と低減, 日本音響学会誌, 第 60 巻, 第 9 号, pp.549-554, 2004.9

8) Park, C. B., Miller, R. D. and Xia, J.: Multichannel Analysis of Surface Waves, Geophysics, Vol. 64, No. 3, pp.800-808, 1999.5

9) Hayashi, K. and Suzuki, H.: CMP Cross-Correlation Analysis of Multi-Channel Surface-Wave Data, Exploration Geophysics, Vol. 35, No. 1, pp.7-13, 2004.3

10) Aki, K.: Space and Time Spectra of Stationary Stochastic Waves, with Special Reference to Microtremors, Bull. Earthq. Res. Inst., Vol. 35, pp.415-456, 1957.1

11) Okada, H.: The Microtremor Survey Method, Geophysical Monograph Series, 12, Society of Exploration Geophysicists, 2003

12) Tsuno, S., Cornou, C. and Bard, P. Y.: Superficial S-wave Velocity and Damping Factor Model Determined by the MASW Measurement in the Grenoble Sedimentary Basin, 14th World Conference on Earthquake Engineering, Paper P034, 2008.10

13) Tsuno, S. and Kudo, K.: Valuation for Practical Use of S-Wave Velocity Structure Determined by the Spatial Auto-Correlation Method Applied for Microtremors, Journal of Structural and Construction Engineering (Transactions of AIJ), No. 596, pp.17-24, 2005.10 (in Japanese) 津野靖士，工藤一嘉 : 微動を用いた空間自己相関法による $\mathrm{S}$ 波速度構造 の実務利用への評価, 日本建築学会構造系論文集, 第 596 号, pp.17-24, 2005.10

14) Capon, J.: High-Resolution Frequency-Wavenumber Spectrum Analysis, Proc. IEEE, Vol. 57, No. 8, pp.1408-1418, 1969.8

15) Yamanaka, H. and Ishida, H.: Application of Genetic Algorithms to an Inversion of Surface-Wave Dispersion Data, Bull. Seism. Soc. Am., Vol. 86, No. 2, pp.436-444, 1996.4

16) Harkrider, D. G.: Surface Waves in Multilayered Elastic Media I, Bull. Seism. Soc. Am., Vol. 54, No. 2, pp.627-679, 1964.4

17) Utsu, T.: Seismology, Kyoritsu Shuppan, 1984 (in Japanese) 宇津徳治 : 地震学, 共立出版, 1984 


\title{
INVESTIGATION ON THE APPLICABILITY OF THE EMPIRICAL PREDICTION METHOD
} TO CONSTRUCTION VIBRATIONS

\author{
Seiji TSUNO ${ }^{* 1}$, Masanori NOYORI ${ }^{* 2}$ and Hidefumi YOKOYAMA*3 \\ ${ }^{* 1}$ Assist. Senior Researcher, Railway Technical Research Institute, Dr.Eng. \\ *2 Researcher, Railway Technical Research Institute, M.Eng. \\ ${ }^{* 3}$ Chief Researcher, Railway Technical Research Institute, Dr.Eng.
}

There are many reports applied the theory of wave propagation in an elastic half-space medium to predict environmental vibrations such as, traffic vibrations, railway-induced ground vibrations, factory vibrations and construction vibrations. In general, the empirical methods simplified the equation by Bornitz were practically used in the engineering fields; however, the applicability of those empirical methods were not clear enough, due to less usage of velocity of subsurface layer which is the most important key-parameter to predict environmental vibrations in a site. To simply and accurately evaluate construction vibrations in one of the environmental vibrations, therefore, we investigated on the applicability of the empirical prediction method based on the theory of wave propagation to construction vibrations, using velocity of subsurface layer.

At first, we performed linear array measurements for 4 types of construction vibrations at a site. We deployed 8 to 10 stations, which are composed of vibration level meters and data loggers, with an interval distance of $5 \mathrm{~m}$ in a linear array. We recorded the vibrations induced by large-sized construction equipment such as a power shovel, a bulldozer and silent piler. The accelerations for 4 types of construction vibrations had the same tendency that the amplitudes were dominated in a frequency of 4 to $40 \mathrm{~Hz}$ at a distance of $2 \mathrm{~m}$ or $5 \mathrm{~m}$ from construction sources, especially at a frequency of $10 \mathrm{~Hz}$ in a linear array. Also, we performed a surface wave exploration and array microtremor observations to estimate phase velocity of Rayleigh waves and S-wave velocity structure at the site. As to the surface wave exploration, we deployed 24 stations with an interval distance of $2 \mathrm{~m}$ in a linear array. As to array microtremor observations, we deployed 7 stations in a double equilateral triangle and its center with a side length of 2 to $60 \mathrm{~m}$. We applied the F-K method to data of surface wave exploration and the SPAC method to vertical data of array microtremor observations respectively, to obtain the phase velocity of Rayleigh waves in a broadband. We inverted S-wave velocity structures from the phase velocity in the inversion technique of the Genetic algorithm.

We applied the wave propagation equation to construction vibrations, to identify wave types of construction vibrations and investigate the validity of velocity of subsurface layer. In case of the identification of wave types, we found that construction vibrations were dominated by surface waves, especially Rayleigh waves in vertical components. In case of the validity of velocity of subsurface layer, we found that the phase velocity of surface waves in a subsurface layer was the most important key-parameter to accurately predict construction vibrations. We calculated the distributions of amplitudes of the fundamental mode Rayleigh waves against depth for frequencies of 5 and $10 \mathrm{~Hz}$ at the site and therefore; we found that the construction vibrations dominated at a frequency of $10 \mathrm{~Hz}$ were significantly affected by the subsurface layer to a depth of $3 \mathrm{~m}$. Finally, we evaluated the peak ground acceleration (PGA) of construction vibrations again distances from construction sources, by the empirical prediction method based on the theory of wave propagation. By properly substituting the frequency dominated in construction vibrations and the phase velocity of surface waves in a subsurface layer at the site to the equation of wave propagation, we could accurately reproduce construction vibrations against distances from construction sources. 